FOLIA POMERANAE UNIVERSITATIS TECHNOLOGIAE STETINENSIS

Folia Pomer. Univ. Technol. Stetin., Oeconomica 2017, 335(87)2, 293-304

Tomasz ZYGMAŃSKI

\title{
ZAJĘCIA LABORATORYJNE JAKO METODA PRAKTYCZNEGO NAUCZANIA RACHUNKOWOŚCI. OPINIE STUDENTÓW WYDZIAŁU NAUK EKONOMICZNYCH I ZARZĄDZANIA UNIWERSYTETU SZCZECIŃSKIEGO
}

\section{LABORATORY EXERCISES AS THE METHOD OF PRACTICAL TEACHING ACCOUNTING. OPINIONS OF STUDENTS OF THE FACULTY OF ECONOMICS AND MANAGEMENT OF THE UNIVERSITY OF SZCZECIN}

Instytut Rachunkowości, Uniwersytet Szczeciński

ul. Adama Mickiewicza 64, 71-100 Szczecin, e-mail: tomasz.zygmanski@usz.edu.pl

\begin{abstract}
Summary. A purpose of the article is a evaluation of laboratory exercises as methods of the practical learning of accounting, effected by students of The Faculty of Economics and Management of the University of Szczecin. In the article results of the questionnaire survey were presented showed that the level of laboratory exercises from accounting in the department was satisfactory. An improvement of the quality of conducted classes is important. University teachers should above all acquire practical experience.
\end{abstract}

Słowa kluczowe: praktyczne metody nauczania, ćwiczenia laboratoryjne, metoda projektu, rachunkowość.

Key words: practical teaching methods, laboratory exercises, method of the project, accounting.

\section{WSTĘP}

Metody i środki nauczania należy dobierać odpowiednio do sytuacji dydaktycznej. Nauczyciel akademicki powinien umieć dobrać najbardziej odpowiednią metodą nauczania. Wybór ten wpływa bezpośrednio między innymi na uzyskane wyniki nauczania. Oprócz przyswojenia wiedzy w procesie dydaktycznym, zwłaszcza w wypadku rachunkowości, istotne znaczenie ma kształtowanie praktycznych umiejętności i nawyków u studentów. Metody nauczania oparte na działaniu sprzyjają lepszemu przyswajaniu i pogłębianiu wiedzy. Stosowanie praktycznych metod nauczania prowadzi do większej skuteczności nauczania i uczenia się, motywowania studentów do działania, rozwijania ich twórczego myślenia, łączenia wiedzy z różnych obszarów, umiejętności pracy zespołowej oraz organizowania pracy własnej.

W nauczaniu rachunkowości, w tym sprawozdawczości finansowej, wykorzystuje się różne metody. W ośrodkach uniwersyteckich do najbardziej popularnych należą wykłady i ćwiczenia. Jednak rachunkowość jako nauka stosowana wymusza również stosowanie praktycznych metod nauczania. Należą do nich ćwiczenia laboratoryjne, które umożliwiają studentom zapoznanie się z podstawowymi funkcjami programów komputerowych wykorzystywanych w praktyce przez służby finansowo-księgowe. Łączenie wykładów, ćwiczeń i ćwiczeń laboratoryjnych pozwala zwiększyć skuteczność nauczania przedmiotów z zakresu rachunkowości. 
Celem artykułu jest przedstawienie oceny przydatności ćwiczeń laboratoryjnych jako metody praktycznej nauki rachunkowości na przykładzie badania dokonanego wśród studentów Wydziału Nauk Ekonomicznych i Zarządzania Uniwersytetu Szczecińskiego (WNEiZ US).

Artykuł składa się z pięciu głównych części: wprowadzenia, opisu stosowanych metod badawczych i procedury pozyskiwania materiałów, naszkicowania tła teoretycznego omawianych zagadnień, wyników badań ankietowych oraz podsumowania.

\section{MATERIA I METODY}

$\mathrm{Na}$ potrzeby artykułu przestudiowano literaturę z zakresu metod nauczania i dydaktyki. Zastosowano analizę źródeł oraz badania ankietowe przeprowadzone wśród studentów WNEiZ US. Ankietę wypełniło 69 studentów zaproszonych do udziału w badaniu drogą mailową i za pomocą jednego z popularnych portali społecznościowych. Respondenci wypełniali kwestionariusz (dostępny w trybie online) zawierający 28 pytań, dotyczących oceny: 1) przedmiotu prowadzonego w formie ćwiczeń laboratoryjnych;

2) pożądanych cech nauczyciela akademickiego prowadzącego zajęcia praktyczne i ich występowania u nauczycieli WNEiZ US;

3) przygotowania nauczycieli akademickich do zajęć oraz sposobu i formy ich prowadzenia;

4) stopnia trudności obsługi i powszechności stosowania w polskich jednostkach gospodarczych programów komputerowych wykorzystywanych na zajęciach praktycznych na WNEiZ US;

5) korzystania przez nauczycieli WNEiZ US z przykładów i / lub opisów zjawisk społeczno-gospodarczych;

6) przydatności ćwiczeń laboratoryjnych w praktycznej nauce rachunkowości.

Pytania zawarte w ankiecie miały charakter zamknięty. Większość z nich wymagała dokonania oceny według pięciostopniowej skali Likerta, która jest powszechnie stosowana w badaniach społecznych.

\section{METODA PROJEKTU JAKO SPOSÓB PRAKTYCZNEGO NAUCZANIA RACHUNKOWOŚCI}

W procesie edukacyjnym kluczową rolę odgrywa nauczyciel. Zrealizowanie celów edukacyjnych jest możliwe dzięki przekazanej w procesie kształcenia wiedzy teoretycznej, praktycznej oraz kompetencji nauczyciela. Przez kształcenie rozumieć należy nie tylko nauczanie, ale też uczenie się (Polak 2013), co oznacza, że nie jest ono możliwe wyłącznie dzięki zaangażowaniu nauczyciela. Proces ten, oprócz aktywności osoby przekazującej treści programowe (nauczyciela), wymaga przede wszystkim zaangażowania odbiorcy (studenta). Wśród podstawowych celów kształcenia należy wyróżnić (Nowoczesne metody dydaktyczne w procesie kształcenia 2013):

1) zdobycie przez studenta podstawowej wiedzy naukowej,

2) przygotowanie studenta do efektywnego wykorzystania wiedzy naukowej w praktyce,

3) zwiększenie zdolności poznawczych studenta,

4) rozwój zainteresowań studenta, odkrywanie jego umiejętności i wzbudzanie motywacji poznawczych. 
Studentów trudno jest zainteresować nauczanym przedmiotem. Rozbudzenie zainteresowania studentów wymaga dobrania odpowiednich metod nauczania. Według Kupisiewicza (1993) metoda nauczania to „[...] celowo i systematycznie stosowany sposób pracy nauczyciela z uczniami, umożliwiający uczniom opanowanie wiedzy wraz z umiejętnością posługiwania się nią w praktyce, a także rozwijanie zdolności i zainteresowań poznawczych uczniów" (s. 352).

Istnieje wiele metod nauczania przydatnych w edukacji. Ich wybrane klasyfikacje są zaprezentowane w tab. 1.

Tabela 1. Wybrane klasyfikacje metod nauczania

\begin{tabular}{|c|c|}
\hline $\begin{array}{c}\text { Autor klasyfikacji metod } \\
\text { nauczania }\end{array}$ & Metody nauczania \\
\hline C. Kupisiewicz & $\begin{array}{l}\text { oparte na: } \\
-\quad \text { słowie } \\
-\quad \text { obserwacji i pomiarze } \\
-\quad \text { działalności praktycznej }\end{array}$ \\
\hline B. Nawroczyński & $\begin{array}{l}\text { - } \text { podające } \\
\text { - poszukujące } \\
\text { - laboratoryjne }\end{array}$ \\
\hline Z. Wiatrowski & $\begin{array}{l}\text { - podające } \\
\text { - poszukujące } \\
\text { - } \text { kierowania samodzielną pracą uczniów }\end{array}$ \\
\hline K. Kruszewski & $\begin{array}{l}- \text { słowne } \\
\text { - oglądowe } \\
\text { - } \text { praktyczne } \\
-\quad \text { gier dydaktycznych }\end{array}$ \\
\hline W. Okoń & $\begin{array}{ll}- & \text { podające (uczenie się przez przyswajanie) } \\
- & \text { problemowe (uczenie się przez odkrywanie) } \\
- & \text { waloryzacyjne (uczenie się przez przeżywanie) } \\
- & \text { praktyczne (uczenie się przez działanie) }\end{array}$ \\
\hline L.J. Lernen i M.N. Skatin & $\begin{array}{l}\text { - objaśniająco-poglądowe (reprodukcyjne), w tym: pokaz, wykład, lektura, pro- } \\
\text { gramy radiowe i telewizyjne itp. } \\
\text { - } \\
\text { problemowe, w tym: wykład, obserwacja, praca z książką, eksperyment i wy- } \\
\text { cieczka } \\
\text { - } \text { częściowo poszukujące, w tym: samodzielna praca uczniów, układanie planu } \\
\text { rozwiązania określonego problemu teoretycznego lub praktycznego, lub wy- } \\
\text { konanie projektu badawczego } \\
\text { - } \text { badawcze, w tym: studiowanie literatury przedmiotu, opracowywanie planu } \\
\text { badań, wysuwanie i weryfikowanie hipotez oraz stosowanie uzyskanej wiedzy }\end{array}$ \\
\hline H. Peterssen & $\begin{array}{l}\text { - } \text { bezpośredniego kierowania pracą uczniów przez nauczyciela } \\
\text { - } \quad \text { projektów } \\
\text { - } \quad \text { inspirujące i motywujące uczniów do nauki }\end{array}$ \\
\hline
\end{tabular}

Źródło: opracowano na podstawie: Francuz (1995); Kupisiewicz (2005).

Przedstawione zestawienie obrazuje zróżnicowanie poglądów dydaktyków nt. klasyfikacji metod nauczania. Jednak każdy z nich uwzględnia, między innymi, metody polegające na zaangażowaniu praktycznym uczniów. W zależności od przyjętej klasyfikacji są to metody działalności praktycznej, laboratoryjne, kierowania samodzielną pracą uczniów, praktyczne, tj. uczenia się poprzez działanie, częściowo poszukujące czy metody projektów.

Jeden z najprostszych podziałów metod nauczania opiera się na uwzględnieniu trzech grup metod, tj. metod opartych na słowie, na obserwacji i pomiarze oraz na działalności praktycznej. Do ostatniej grupy metod należą metody zajęć laboratoryjnych i czynności praktycznych wykonywanych przez studentów, które najczęściej są powiązane z czynnościami teoretycznymi (Kupisiewicz 2005). Metoda zajęć praktycznych polega na stosowaniu w działalności nabytej 
wiedzy teoretycznej. Służy ona rozwijaniu i pogłębianiu wiedzy studenta. Efektywne korzystanie z tej metody wymaga (Pedagogika - metody nauczania, http://pedagogika.wiedza.diaboli.pl/):

1) określenia nazwy i znaczenia umiejętności rozwijanych podczas zajęć;

2) wskazania przez nauczyciela reguł postępowania, wzorców wykonywania czynności;

3) monitorowania czynności wykonywanych przez studentów;

4) samodzielnego wykonywania przez studentów ćwiczeń rozłożonych w czasie.

Często problem dydaktyczny stanowią zajęcia o podobnym zakresie, np. przedmioty związane z rachunkowością. Studenci odnoszą wówczas błędne wrażenie, że to, co przekazuje nauczyciel, jest im już znane, przynajmniej w jakiejś części (Siekiera 2015). W związku z tym nauczyciele akademiccy powinni wykorzystywać w swojej pracy metody aktywizujące, umożliwiające studentom samodzielne zdobywanie wiedzy. Studenci jako osoby dorosłe są bowiem zdolni do podejmowania, formułowania i rozwiązywania problemów, a zdobyta samodzielnie wiedza jest bardziej trwała (Szewczuk 2013).

Aktywizowanie studentów w procesie dydaktycznym oznacza stymulowanie, wspieranie i rozbudzanie oczekiwań poznawczych studentów oraz pomaganie w ich realizacji przez nauczyciela (Nadolna i Skulmowski 2012). Angażuje to studentów emocjonalnie, zwiększa ich zaangażowanie oraz motywację, uczy samodzielnego myślenia i działania. Aktywizacji studentów sprzyja zastosowanie metody projektów, powszechnie stosowanej na ćwiczeniach laboratoryjnych.

$\mathrm{Na}$ tych zajęciach rozwiązywanie problemów przez studenta, bez pomocy nauczyciela, przynosi długotrwałe rezultaty. Ważnymi cechami uczenia się przez działalność praktyczną jest fakt, że student bardziej skupia się na nauce, a proces uczenia się przebiega według jego indywidualnych zdolności i umiejętności (Shah i Rahat 2014). Metoda zajęć praktycznych obejmuje szeroki zakres czynności studentów, w tym przykładowo obsługę zaawansowanych systemów finansowo-księgowych na ćwiczeniach laboratoryjnych z rachunkowości. W metodzie tej na pierwszy plan wysuwa się kształtowanie i rozwijanie u studentów umiejętności przydatnych w przyszłej pracy zawodowej. W gospodarce opartej na wiedzy umiejętności praktyczne wymagają solidnej podbudowy teoretycznej (Kupisiewicz 2005). Z tego względu ćwiczenia laboratoryjne poprzedzane są wykładami i tradycyjnymi ćwiczeniami.

\section{PRAKTYCZNA NAUKA RACHUNKOWOŚCI NA WYDZIALE NAUK EKONOMICZNYCH I ZARZĄDZANIA UNIWERSYTETU SZCZECIŃSKIEGO}

$\mathrm{Na}$ WNEiZ US zajęcia praktyczne nazywane są ćwiczeniami laboratoryjnymi. Wbrew nazwie nie bazują one na metodzie laboratoryjnej, która polega na przygotowaniu zajęć, podczas których nauczyciel umożliwia studentom przeprowadzenie eksperymentów (doświadczeń) biologicznych, chemicznych, fizycznych itp. (Kupisiewicz 2005). Ćwiczenia laboratoryjne na WNEiZ US, jako forma zajęć o charakterze praktycznym, są realizowane w celu przybliżenia studentom rzeczywistości gospodarczej, z którą będą musieli zmierzyć się po zakończeniu studiów. Nauczyciele akademiccy, prowadzący ćwiczenia laboratoryjne z przedmiotów z zakresu rachunkowości, powszechnie stosują metodę projektów. Oznacza to, że student ma za zadanie rozwiązać rzeczywisty problem lub stworzyć nową koncepcję. Jest to możliwe dzięki przeprowadzeniu symulacji pracy projektowej, której efekty służą celom 
dydaktycznym (Lubina 2005). Umiejscowienie wśród metod nauczania, według klasyfikacji zaproponowanej przez Szlosek (1995), metody stosowanej na ćwiczeniach laboratoryjnych z rachunkowości na WNEiZ US jest przedstawione na ryc. 1.

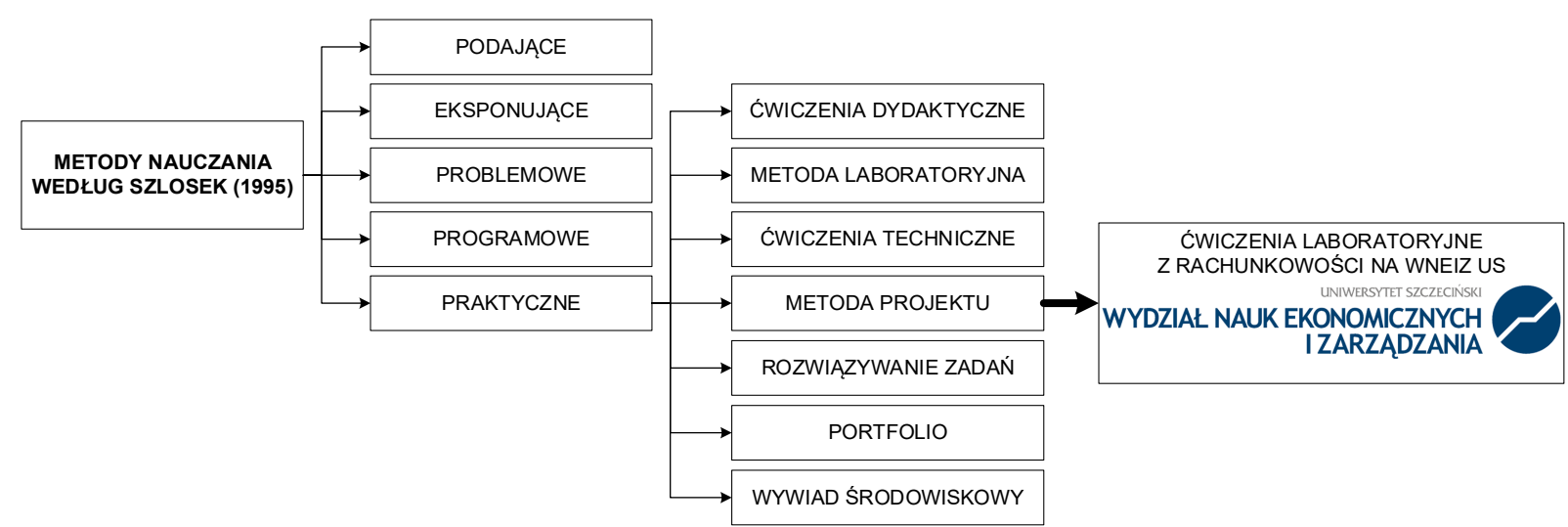

Ryc. 1. Metody nauczania a metoda projektu stosowana na ćwiczeniach laboratoryjnych z rachunkowości na WNEiZ US

Żródło: opracowano na podstawie Szlosek (1995).

Praktyczne metody nauczania rachunkowości na WNEiZ US są stosowane na studiach stacjonarnych i niestacjonarnych I i ll stopnia. W trakcie studiów w każdym semestrze studenci mają możliwość praktycznej nauki rachunkowości na ćwiczeniach laboratoryjnych. Do przedmiotów prowadzonych w tej formie na WNEiZ US między innymi zalicza się:

- sprawozdawczość finansową,

- rachunkowość małych firm,

- rozliczenia publicznoprawne,

- narzędzia informatyczne w finansach i rachunkowości,

- narzędzia organizacji rachunkowości,

- badanie sprawozdań finansowych,

- systemy finansowo-księgowe,

- projektowanie systemu rachunkowości finansowej.

Jako praktyczna nauka rachunkowość wymaga zapoznania studentów z czynnościami wykonywanymi przez osoby uprawiające zawody związane z księgowością. Z tego względu w nauczaniu rachunkowości na WNEiZ US oraz na wielu innych wydziałach ekonomicznych metoda projektu jest powszechnie wykorzystywana. Metoda ta wspierana jest innymi metodami nauczania, wymienionymi w tab. 1. Zastosowanie metody praktycznej (metody projektu) przynosi efekty nauczania (Bernacka 2001) w postaci umiejętności skutecznego działania poprzez wykorzystanie teorii w praktyce.

\section{WYNIKI}

Celem badań przeprowadzonych wśród studentów WNEiZ US uczestniczących w zajęciach z rachunkowości prowadzonych w formie laboratoriów, podczas których pracują samodzielnie na stanowisku komputerowym, było poznanie oceny zajęć praktycznych. Osiągnięciu tego celu posłużyły badania ankietowe przeprowadzone wśród studentów na 
kierunku finanse i rachunkowość na studiach stacjonarnych. Jak już wspomniano, kwestionariusz ankiety udostępniono w formie elektronicznej, a studenci zostali zaproszeni do badania drogą mailową. Zaproszenie do udziału w badaniu umieszczono również na profilu WNEiZ US na jednym z mediów społecznościowych.

Odpowiedzi na pytania zawarte w kwestionariuszu ankiety udzieliło 69 osób, w tym 55 studentek $(80 \%)$ i 14 studentów (20\%), co zostało zaprezentowane na ryc. 2.

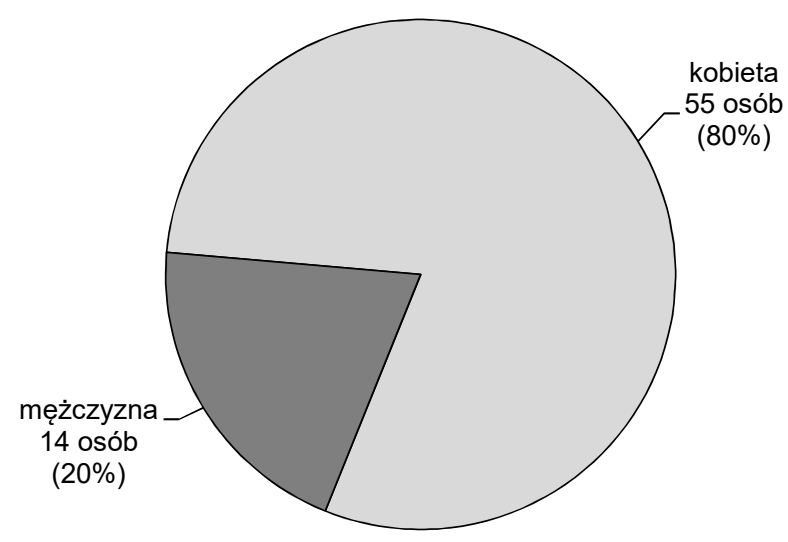

Ryc. 2. Struktura ankietowanych według płci

Źródło: opracowano na podstawie wyników badań ankietowych.

W badaniu wzięli udział przede wszystkim studenci studiów:

a) I stopnia - III rok (24\%),

b) II stopnia, w tym:

- I rok (25\%),

- II rok (29\%).

Szczegółowa struktura została zaprezentowana na ryc. 3 .

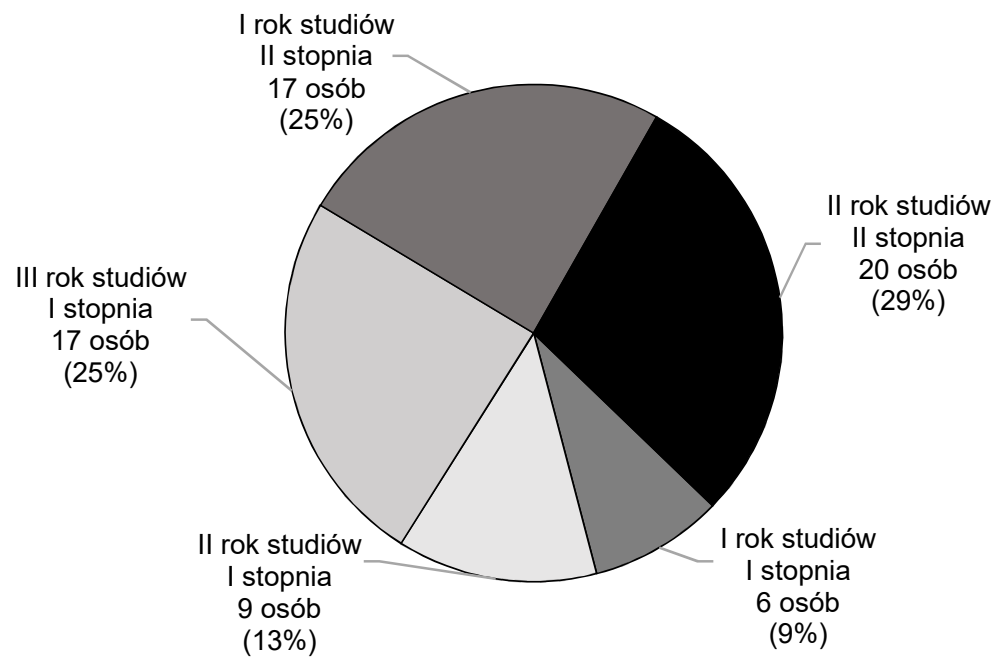

Ryc. 3. Struktura ankietowanych roczników

Źródło: opracowano na podstawie wyników badań ankietowych. 
Ankietowani oceniali ćwiczenia laboratoryjne z przedmiotu, który jako ostatni był prowadzonym w tej formie w trakcie trwania ich studiów (ryc. 4). Do najczęściej ocenianych należały następujące przedmioty:

- rachunkowość małych firm (32\%),

- systemy finansowo-księgowe (17\%),

- narzędzia organizacji rachunkowości (14\%),

- narzędzia informatyczne w finansach i rachunkowości (12\%),

- sprawozdawczość finansowa $(7 \%)$,

- rozliczenia publicznoprawne $(7 \%)$.

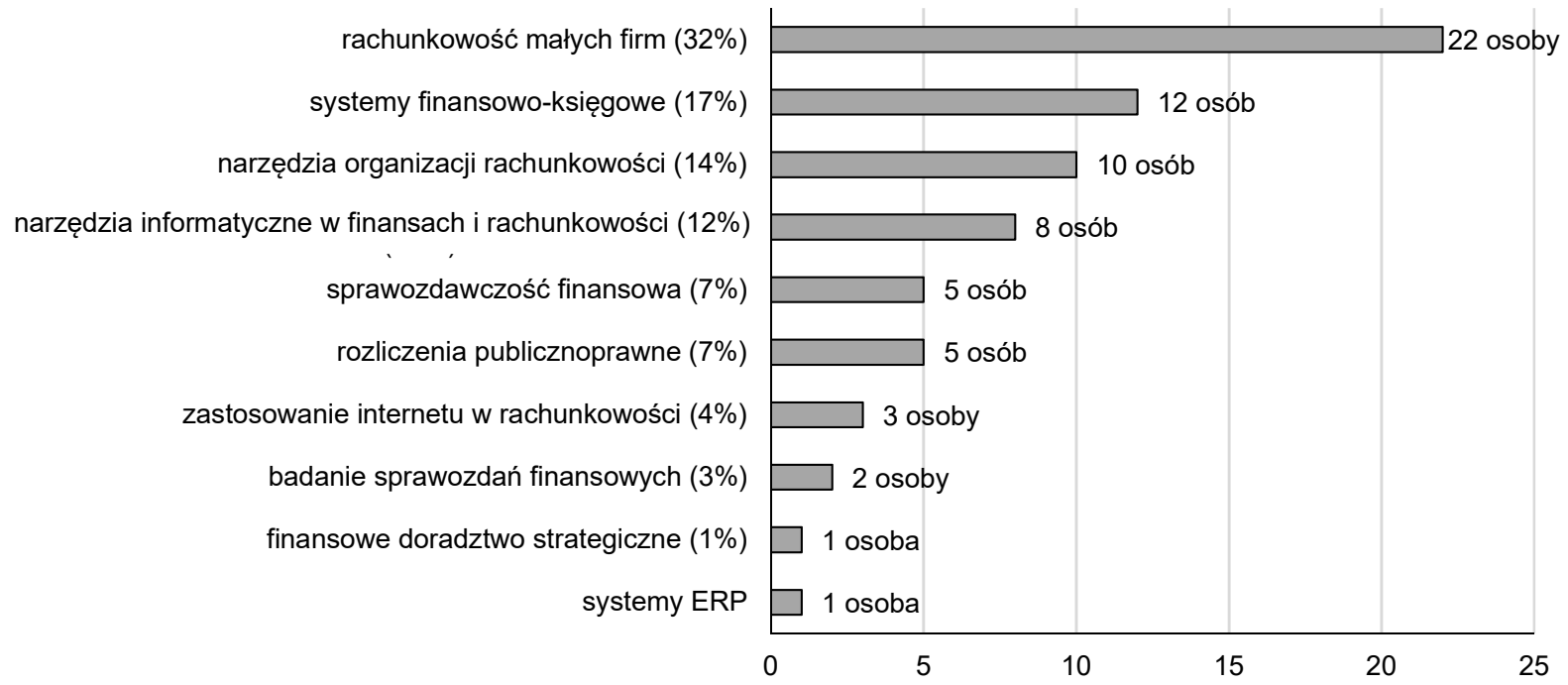

Ryc. 4. Przedmioty oceniane przez ankietowanych

Źródło: opracowano na podstawie wyników badań ankietowych.

Znaczna część ankietowanych potwierdziła systematyczny udział w ocenianych zajęciach (86\%), tj. 81-100\% obecności, co pozwala uznać otrzymane wyniki za wiarygodne. Uczestnictwo studentów w zajęciach laboratoryjnych prezentuje ryc. 5 .

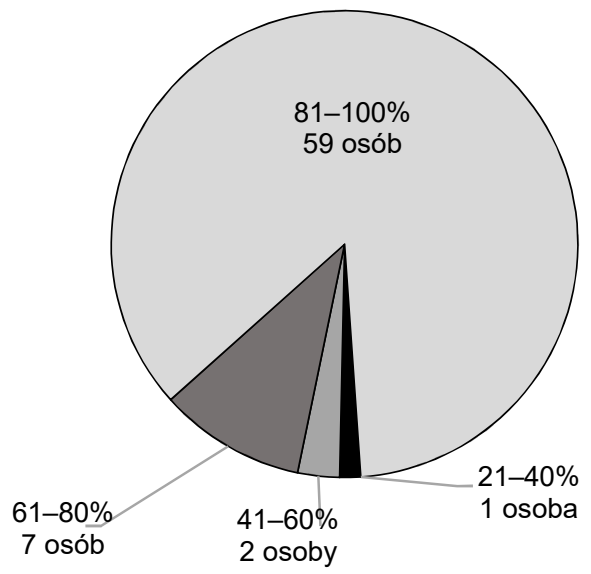

Ryc. 5. Obecność ankietowanych na zajęciach z ocenianych przedmiotów Źródło: opracowano na podstawie wyników badań ankietowych. 
Kolejne pytanie dotyczyło wskazania cech pożądanych u nauczycieli akademickich prowadzących zajęcia praktyczne z zakresu rachunkowości. Nauczyciele prowadzący zajęcia związane z praktyczną nauką rachunkowości zdaniem ankietowanych powinni odznaczać się cechami takimi, jak:

- profesjonalizm, kompetencje merytoryczne, techniczne oraz wychowawcze (22\%);

- umiejętne przekazywanie wiedzy (19\%);

- łączenie wiedzy praktycznej z teoretyczną (16\%).

Do cech nieistotnych studenci zaliczyli:

- cierpliwość i otwartość na zmiany (6\%),

- umiejętność indywidualizacji nauczania (3\%),

- posługiwanie się językiem technicznym (3\%).

Wyniki badań dotyczące pożądanych cech nauczycieli prowadzących zajęcia laboratoryjne z rachunkowości przedstawia ryc. 6 .

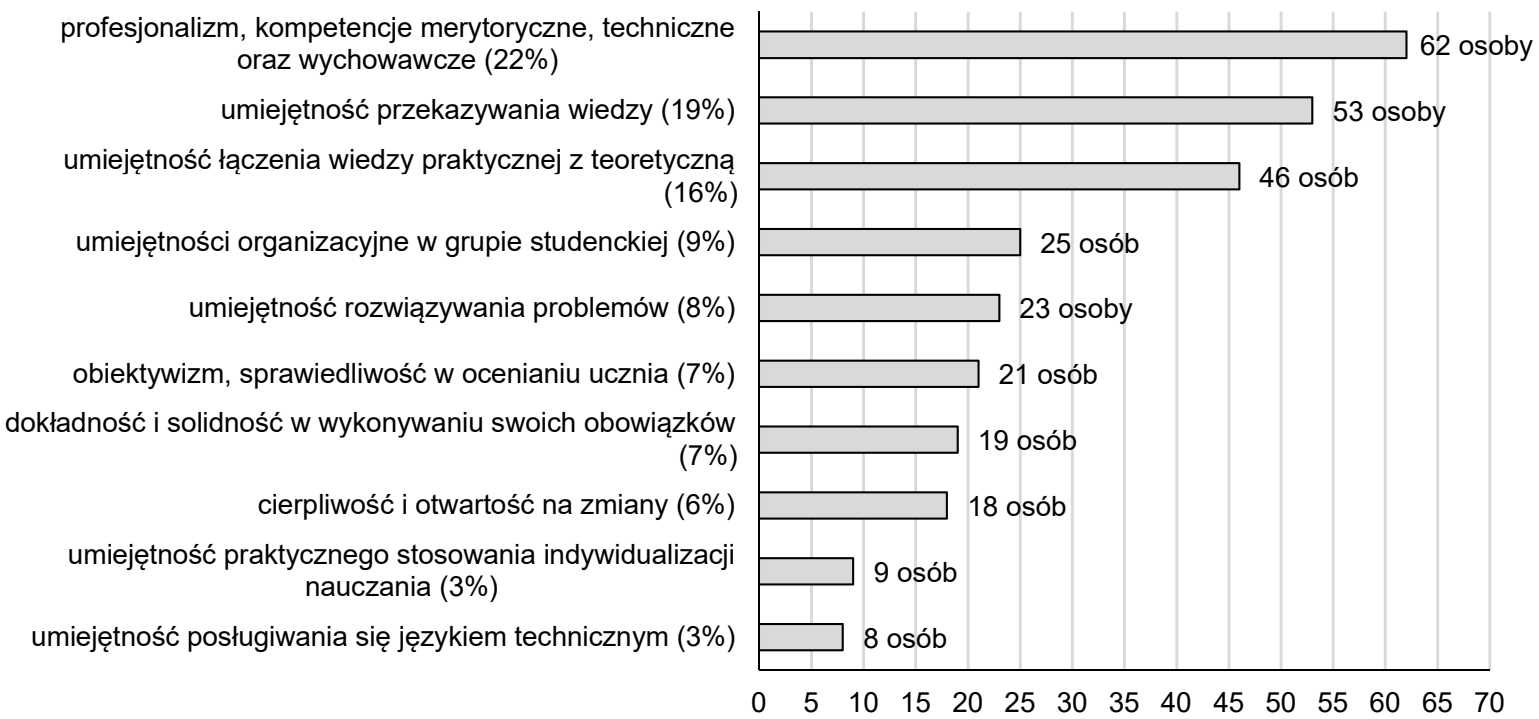

Ryc. 6. Cechy pożądane u nauczycieli prowadzących zajęcia laboratoryjne rachunkowości Źródło: opracowano na podstawie wyników badań ankietowych.

Od szóstego pytania studenci oceniali zajęcia praktyczne z rachunkowości z użyciem pięciostopniowej skali Likerta (z wyjątkiem pytań 15, 18 i 28). Odpowiedzi na pytania 6-14, 16-17 oraz 19-27 zaprezentowano w tab. 2.

Prawie połowa (49\%) prowadzących na WNEiZ US ćwiczenia związane z praktyczną nauką rachunkowości przekazuje dodatkowe materiały i informacje ułatwiające studentom pracę na zajęciach (ryc. 7). Do materiałów tych należą, między innymi, zestawy zadań do samodzielnego wykonania lub instrukcje dotyczące rozwiązywania określonych problemów z użyciem odpowiedniego narzędzia, np. programu finansowo-księgowego. 
Tabela. 2. Wyniki ankiety uzyskane na podstawie pytań 6-14, 16-17 oraz 19-27

\begin{tabular}{|c|c|c|c|c|c|c|}
\hline \multirow{3}{*}{ Treść pytania } & \multicolumn{5}{|c|}{ Odpowiedzi } & \multirow{3}{*}{$\begin{array}{c}\text { Średnia } \\
\text { ważona } \\
\text { (liczba } \\
\text { odpowiedzi } \\
\text { x ocena) }\end{array}$} \\
\hline & $\begin{array}{c}1-\text { zde- } \\
\text { cydowanie } \\
\text { nie zgadzam } \\
\text { się }\end{array}$ & $\begin{array}{c}2 \text { - raczej } \\
\text { nie zgadzam } \\
\text { się }\end{array}$ & $\begin{array}{l}3 \text { - nie mam } \\
\text { zdania }\end{array}$ & $\begin{array}{l}4-\text { raczej } \\
\text { zgadzam się }\end{array}$ & $\begin{array}{c}5-\text { zde- } \\
\text { cydowanie } \\
\text { zgadzam się }\end{array}$ & \\
\hline & \multicolumn{5}{|c|}{ Liczba odpowiedzi } & \\
\hline $\begin{array}{l}\text { 6. Nauczyciel akademicki WNEiZ US, który prowadził ćwiczenia laboratoryjne z rachunkowości, } \\
\text { posiadał pożądane cechy }\end{array}$ & 5 & 12 & 11 & 30 & 11 & 3,43 \\
\hline 7. Moje przygotowanie do zajęć w formie ćwiczeń laboratoryjnych było bardzo dobre & 1 & 6 & 11 & 40 & 11 & 3,78 \\
\hline 8. Prowadzący ćwiczenia laboratoryjne był bardzo dobrze przygotowany do zajęć & 2 & 12 & 11 & 25 & 19 & 3,68 \\
\hline $\begin{array}{l}\text { 9. Prowadzacy ćwiczenia laboratoryjne przedstawiał omawiane treści w sposób bardzo } \\
\text { zrozumiały }\end{array}$ & 5 & 13 & 12 & 24 & 15 & 3,45 \\
\hline $\begin{array}{l}\text { 10. Prowadzący ćwiczenia laboratoryjne przedstawiał omawiane treści w sposób bardzo } \\
\text { interesujący }\end{array}$ & 13 & 15 & 22 & 12 & 7 & 2,78 \\
\hline 11. Prowadzący ćwiczenia laboratoryjne utrzymywał odpowiednie tempo zajęć & 11 & 9 & 16 & 19 & 14 & 3,23 \\
\hline 12. Użyte przez prowadzącego ćwiczenia laboratoryjne formy prezentacji były właściwe & 6 & 4 & 14 & 22 & 23 & 3,75 \\
\hline $\begin{array}{l}\text { 13. Użyte przez prowadzącego ćwiczenia laboratoryjne programy komputerowe były właściwe } \\
\text { ze względu na trudność ich obsługi przez niedoświadczone osoby }\end{array}$ & 3 & 5 & 17 & 29 & 15 & 3,70 \\
\hline $\begin{array}{l}\text { 14. Użyte przez prowadzącego ćwiczenia laboratoryjne programy komputerowe były właściwe } \\
\text { ze względu na ich powszechne stosowanie w praktyce }\end{array}$ & 1 & 5 & 19 & 26 & 18 & 3,80 \\
\hline 16. Prowadzący ćwiczenia laboratoryjne był bardzo zaangażowany w prowadzenie zajęć & 1 & 10 & 12 & 26 & 20 & 3,78 \\
\hline $\begin{array}{l}\text { 17. Prowadzący ćwiczenia bardzo dbał o atmosferę zajęć sprzyjającą uczeniu się (np. sposób } \\
\text { zwracania się do studentów, dbanie o ciszę podczas zajęć) }\end{array}$ & 3 & 6 & 13 & 27 & 20 & 3,80 \\
\hline $\begin{array}{l}\text { 19. Przykłady odwołujące się do praktyki i/lub zjawisk społeczno-gospodarczych, przedstawiane } \\
\text { przez prowadzącego ćwiczenia laboratoryjne, były zrozumiałe }\end{array}$ & 1 & 1 & 5 & 15 & 14 & 2,14 \\
\hline $\begin{array}{l}\text { 20. Przykłady odwołujące się do praktyki i/lub zjawisk społeczno-gospodarczych, przedstawiane } \\
\text { przez prowadzącego ćwiczenia laboratoryjne, były interesujące }\end{array}$ & 1 & 1 & 11 & 13 & 10 & 2,00 \\
\hline 21. Ćwiczenia laboratoryjne $z$ rachunkowości są bardzo dobrą metodą nauczania praktycznego & 1 & 2 & 5 & 20 & 41 & 4,42 \\
\hline $\begin{array}{l}\text { 22. Uczestnictwo w ćwiczeniach laboratoryjnych bardzo wzbogaciło moją wiedzę dotyczącą } \\
\text { omawianego tematu }\end{array}$ & 6 & 7 & 18 & 28 & 10 & 3,42 \\
\hline $\begin{array}{l}\text { 23. Wiedza zdobyta na ćwiczeniach laboratoryjnych umożliwia wykonanie określonego zadania } \\
\text { w praktyce (np. ewidencji operacji gospodarczej za pomocą programu FK) }\end{array}$ & 3 & 7 & 12 & 21 & 26 & 3,87 \\
\hline $\begin{array}{l}\text { 24. Ćwiczenia laboratoryjne z rachunkowości na WNEiZ US są bardzo dobrą symulacją } \\
\text { rzeczywistości gospodarczej }\end{array}$ & 6 & 11 & 31 & 15 & 6 & 3,06 \\
\hline $\begin{array}{l}\text { 25. Prowadzącym ćwiczenia laboratoryjne } \mathrm{z} \text { rachunkowości na WNEiZ US brakuje praktycznego } \\
\text { doświadczenia }\end{array}$ & 4 & 17 & 20 & 17 & 11 & 3,20 \\
\hline $\begin{array}{l}\text { 26. Ćwiczenia laboratoryjne z rachunkowości powinny prowadzić wyłącznie osoby z praktycznym } \\
\text { doświadczeniem }\end{array}$ & 1 & 4 & 10 & 18 & 36 & 4,22 \\
\hline 27. Ogólny poziom nauczania praktycznego rachunkowości na WNEiZ US jest bardzo dobry & 3 & 14 & 18 & 27 & 7 & 3,30 \\
\hline
\end{tabular}

Źródło: opracowano na podstawie wyników badań ankietowych. 


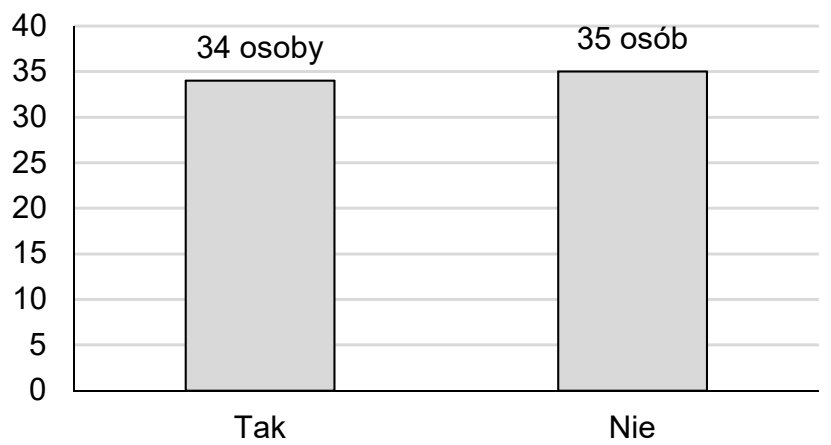

Ryc. 7. Udostępnianie przez nauczycieli akademickich WNEiZ US dodatkowych materiałów i informacji ułatwiających studentom pracę na ćwiczeniach laboratoryjnych z rachunkowości Źródło: opracowano na podstawie wyników badań ankietowych.

Z badań ankietowych wynika, że ponad połowa dydaktyków WNEiZ US (54\%) bazuje wyłącznie na zagadnieniach teoretycznych, przekazując sposoby rozwiązywania konkretnych zadań bez obrazowania omawianych treści przykładami odwołującymi się do praktyki i / lub opisami zjawisk społeczno-gospodarczych (ryc. 8).

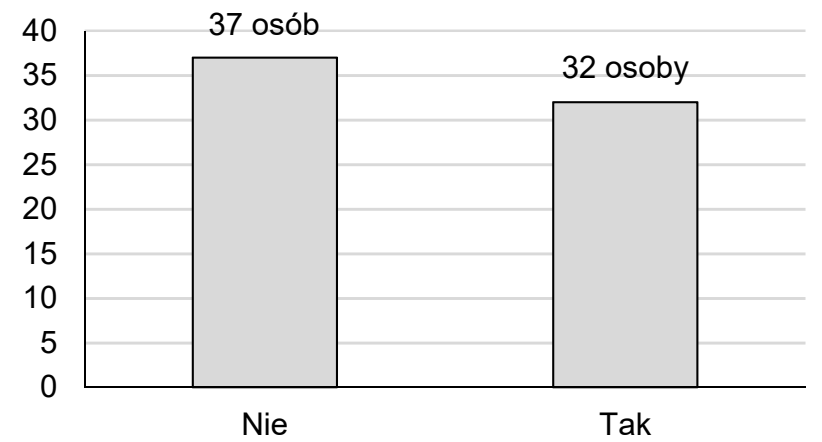

Ryc. 8. Obrazowanie przez nauczycieli akademickich WNEiZ US omawianych treści przykładami odwołującymi się do praktyki i / lub opisami zjawisk społeczno-gospodarczych.

Źródło: opracowano na podstawie wyników badań ankietowych.

Dokonując analizy wyników badań ankietowych, można stwierdzić, że najwyżej ocenianymi przedmiotami dotyczącymi praktycznej nauki rachunkowości na WNEiZ US są:

- rachunkowość małych firm,

- systemy finansowo-księgowe.

Studenci najniżej ocenili przedmiot narzędzia informatyczne w finansach i rachunkowości.

W odpowiedzi na ostatnie pytanie ankietowani studenci mogli przekazać dodatkowe uwagi odnośnie do ćwiczeń laboratoryjnych z rachunkowości na WNEiZ US; jednak tylko 6 osób udzieliło na nie odpowiedzi, pisząc, że:

1) sale komputerowe, w których odbywają się ćwiczenia laboratoryjne są nieodpowiednio wyposażone;

2) zajęcia laboratoryjne $z$ rachunkowości przypominają podstawowe szkolenia z obsługi narzędzi (programów komputerowych), co daje poczucie, że obecność na tych zajęciach jest stratą czasu; 
3) zajęcia tego typu powinny odbywać się w zwiększonym wymiarze godzin;

4) praktyczna nauka rachunkowości powinna obejmować również praktyki / staże w jednostkach gospodarczych zajmujących się na co dzień omawianymi zagadnieniami.

\section{PODSUMOWANIE}

Na podstawie przeprowadzonych badań ankietowych można podjąć próbę oceny ćwiczeń laboratoryjnych na WNEiZ US jako metody praktycznej nauki rachunkowości. Jak wynika z badań, ogólny poziom nauczania praktycznego rachunkowości na Wydziale jest dobry. Jednak studentom trudno jest stwierdzić, czy ćwiczenia laboratoryjne z rachunkowości są adekwatną symulacją rzeczywistości gospodarczej. Może to wynikać z faktu, że większość studentów nie ma praktycznego doświadczenia w zakresie zagadnień omawianych na zajęciach.

Studenci uważają, że dydaktycy powinni przekazywać nie tylko wiedzę teoretyczną, ale również rozwiązania praktyczne. Poziom zadowolenia studentów z posiadania przez nauczycieli doświadczenia praktycznego z poszczególnych przedmiotów jest przeciętny. Studenci wiedzę o praktycznym przygotowaniu nauczycieli uzyskują poprzez nieformalne kanały przekazywania informacji. Dlatego też, zdaniem autora, opinia ta może nie zgadzać się ze stanem faktycznym. Według studentów dydaktycy zatrudnieni na Wydziale posiadają odpowiednie cechy; są to w szczególności: profesjonalizm, odpowiednie kompetencje merytoryczne, techniczne i wychowawcze, właściwe przekazywanie wiedzy teoretycznej oraz prawidłowe łączenie jej z wiedzą praktyczną. Poziom nauczania rachunkowości na WNEiZ US oceniają więc studenci jako zadowalający.

Wyniki badań wykazują, że studenci przychodzą na zajęcia przygotowani. Dostrzegają zaangażowanie pracowników Wydziału, którzy są właściwie przygotowani do zajęć i prowadzą je w sposób interesujący. W odczuciu studentów nauczyciele akademiccy wykazują zaangażowanie, realizując prowadzone przedmioty, stwarzają atmosferę sprzyjającą uczeniu się. Dostosowują tempo prowadzonych zajęć do potrzeb i możliwości studentów, a stosowane przez nich formy prezentacji są właściwe. Programy komputerowe niezbędne do praktycznej nauki rachunkowości są dobrze dobrane pod względem stopnia trudności ich obsługi przez niedoświadczone osoby. Dobór stosowanych programów pod względem powszechności ich stosowania w praktyce również jest prawidłowy.

Negatywną stroną zajęć laboratoryjnych z rachunkowości na WNEiZ US jest bazowanie, przede wszystkim, na wiedzy teoretycznej. Wielu nauczycieli nie prezentuje omawianych zagadnień na przykładach odwołujących się do praktyki. Jeżeli nawet nauczyciele próbują przedstawiać przykłady z praktyki, to są one niezrozumiałe i mało interesujące dla studentów. Zdaniem autora problem ze zrozumieniem zaprezentowanych przykładów może wynikać z nieodpowiedniego zasobu wiedzy studentów. Jednak studenci uważają, że udział w ćwiczeniach laboratoryjnych bardzo wzbogacił ich wiedzę dotyczącą poszczególnych zagadnień z rachunkowości. Ich zdaniem wiedza zdobyta na zajęciach umożliwia wykonanie określonego zadania w praktyce.

Zdecydowana większość studentów uważa ćwiczenia laboratoryjne za bardzo dobrą metodę praktycznej nauki rachunkowości. W związku z tym należy postulować, aby wymiar zajęć prowadzonych $w$ tej formie był stosunkowo duży. Ponadto należy zatroszczyć się 
o poprawę jakości prowadzonych zajęć, aby w maksymalnym stopniu sprostać wymaganiom stawianym przez studentów. Sprzyjałby temu, między innymi, udział nauczycieli akademickich w stażach podnoszących umiejętności i kompetencje dydaktyczne w zakresie różnych programów finansowo-księgowych.

\section{PIŚMIENNICTWO}

Bernacka D. 2001. Od słowa do działania. Warszawa, Wydaw. Akad. „Żak”.

Francuz W.M. 1995. Dydaktyka przedmiotów zawodowych. Przewodnik metodyczny dla słuchaczy studiów pedagogicznych w wyższych uczelniach technicznych. Kraków, PKrak.

Kupisiewicz C. 1993. Encyklopedia pedagogiczna. Warszawa, Fundacja „Innowacja”.

Kupisiewicz C. 2005. Podstawy dydaktyki. Warszawa, Wydaw. Szk. Pedagog.

Lubina E. 2005. Metoda projektu w procesie dydaktycznym uczelni wyższej, w: Uczelnia oparta na wiedzy. Organizacja procesu dydaktycznego oraz zarządzanie wiedzą w ekonomicznym szkolnictwie wyższym. Red. T. Gołębiowski, M. Dąbrowski, B. Mierzejewska. Warszawa, Fundacja Promocji i Akredytacji Kierunków Ekonomicznych, 224-231.

Nadolna B., Skulmowski M. 2012. Ocena metod nauczania rachunkowości według opinii studentów Wydziału Ekonomicznego Zachodniopomorskiego Uniwersytetu Technologicznego w Szczecinie. Folia Pomer. Univ. Technol. Stetin., Oeconomica 294(67), 163-174.

Nowoczesne metody dydaktyczne w procesie kształcenia. 2013. Red. K. Czekaj-Kotynia. Łódź, Wydaw. „Piktor”.

Pedagogika - metody nauczania, http://pedagogika.wiedza.diaboli.pl/metody-nauczania-3/, dostęp: 27.07.2016 r.

Polak B. 2013. Podstawy teorii kształcenia. Szczecin, Szcz. Szk. Wyż. Collegium Balticum.

Shah I., Rahat T. 2014. Effect of activity based taching method in science. Inter. J. Hum. Manag. Sci. (IJHMS) 2(1), 39-41, ISSN 2320-4044.

Siekiera R. 2015. Realizacja projektu jako forma praktycznego zaangażowania studentów, w: Twórczość, pasja, uniwersytet. Kategoria zaangażowania w dydaktyce akademickiej. Red. J. Płuciennik, K. Klimczak. Łódź, Wydaw. UŁódz., 131-144.

Szewczuk K. 2013. Metody dydaktyczne stosowane w szkole wyższej. Kraków, Akad. Ignatianum.

Szlosek F. 1995. Wstęp do dydaktyki przedmiotów zawodowych. Radom, Wydaw. ITE. 